\title{
GENEALOGI TEOLOGI NAHDLATUL ULAMA
}

\author{
Suis Qa'imł
}

\begin{abstract}
NU, thelarget soial andreigiausorganizationin Indonesia hasundargnemany dhanges sinceits very inception decades ago But the essene of theorganization remains the same, namiy its thedogical dotrineand "ideological" indination toward the Sumna. This papertriestospeak of thestruggeof NU in this hangingera toremainasit is It traces the thedogical genealogy of the organization, and how this thedogy has been transformed from timetotimetomet thedemands of Indonesian setting HereNU is undastoodas a dynamic religious organization capable of transating cetain theology and idedogy into a toally different look. Hence, although it was criginated in the thedogy of al-Asyaniyzh and alMaturidiyah, NU was not at all representing any of these two Middle Eastem theologes Unlikethetwo, NU emphasizes theretically theides of justice, modeation, and tdeance whilepratically uphddingtheadaptiveandadpptiveattitudetonardlocal astomsandtraditions Keywords: NU, genelogy, justice, moderation, tderance
\end{abstract}

\section{Pendahuluan}

Berbicara tentang organisasi masyarakat (ormas), Nahdlatul Ulama' (NU) adalah salah ormas yang terbesar di Indonesia dan mempunyai kontribusi besar terhadap kemerdekaan Indonesia. NU pulalah yang menyumbangkan para tokohnya untuk ikut rembuk dan bersifat partisipatif dalam penyusunan dasar-dasar negara, sebut saja $\mathrm{KH}$. Wahid putra dari sang founding father NU, KH. Hasyim Asy'ari. Tidak berhenti sampai di sana, pada tahun 1952, NU juga tercatat sebagai salah satu partai politik yang ikut meramaikan pesta demokrasi rakyat Indonesia pada Pemilihan Umum. Namun pada akhirnya, organisasi yang didirikan pada tahun tanggal 31 Januari 1926 ini melepaskan baju partainya setelah pemilu tahun 1971 dan kembali menjadi ormas dengan slogan yang cukup terkenal, kembali ke khittah. ${ }^{1}$

NU adalah organisai Islam yang berhaluan Ahl al-Sumah wa al-Jama'gh D alam bidang

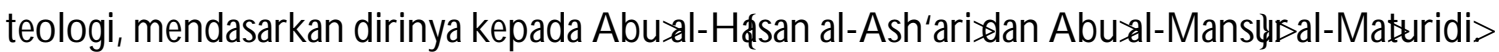
Dalam bidang fikih, bermazhab pada pada salah satu dari Imam Shafi'i $>$ Imam Malik, Imam Abułanifah, dan Imam Ahmad bin Hąnbal. Sedangkan dalam urusan tasawuf, NU berkiblat pada tasawuf al-Gazaki>dan Junayd al-Baghdadi> Selain itu, dalam hidup bersosial dengan masyarakat luas, NU selalu mengedapankan dan menumbuh kembangkan sikap adil dan lurus, penuh toleransi, penuh keseimbangan, dan amar mánuf nahy mukar. Prinsip umum diaplikasikan dalam kehidupan beragama, bermasyarakat, dan bernegara. ${ }^{3}$

Diskursus tentang pemikiran teologi dalam tubuh NU adalah sangat menarik untuk dikaji dalam tulisan ini. Kajian-kajian yang sifatnya dialektis selalu muncul di antara para anggota dan kadernya dengan harapan formulasi prinsip-prinsip dasar yang telah dibangun

*Institut Agama Islam Negeri (IAIN) Sunan Ampel, Surabaya.

${ }^{1}$ Ensklqpedi Indonesia, jil. 4 (Jakarta: Ichtiar Baru van Hoeve, 1980), 2327-2328. Lihat juga dalam Anggaran Dasar NU bab 1 pasal 1 dan Bab II pasal 3.

2Pengurus Wilayah NU Jatim, KeputusanMuktamar NUXXV II (Surabaya: Pengurus Wilayah NU Jatim), 1984, 77-78. Lihatjuga PBNU, KeputusanMunasAlimUlama' danKonbesNUdi BandarLampung(Jakarta: PBNU, 1992), 128.

3Ibid. 
sejak lama terus disempurnakan sehingga menjadikan organisasi NU ini selalu dinamis sepanjang masa. NU ibarat kaca prima yang memantulkan dan membiaskan beragam warna penafsiran. Oleh karena itu, banyak para pengamat dari internal NU ataupun dari atsider yang mencurahkan perhatiannya pada organisasi NU, baik sebagai organisasi kemasyarakatan ataupun sebagai wadah dari kajian-kajian keislaman yang terus menarik untuk dielaborasi lebih dalam. Sebut saja KH. M. A. Sahal Mahfudz yang mengkaji NU dalam bidang fikih. Menurutnya, selain bermazhab secara qavi,>NU harus berani melangkah lebih jauh dengan bermazhab secara manhaij, >yaitu mengikuti metode istinbat\}para imam madhakib al-arba'ah sehingga konklusi hukum yang dihasilkan lebih aplikatif dan dinamis menjawab persoalanpersoalan masyarakat di dunia modern ini. ${ }^{4}$ D alam diskursus tasawuf, Said A qil Siraj memosisikan dirinya sebagai orang yang menggugat tasawuf 'amali menuju tasawuf falsafi (filsafat). ${ }^{5}$ Sedangkan dalam bidang teologi, Khotibul Umam Wirano menggugat teologi $\mathrm{Ah}$ al-Sumah wa al-Jama'gh dari teologi temporer menuju teologi kontemporer. ${ }^{6}$

Selain kajian tentang 3 bidang di atas (fikih, tasawuf, dan teologi), telah banyak karya lahir dari hasil penelitian yang dalam terhadap dinamika NU oleh para pengamat dan peneliti, baik dari dalam negeri maupun dari luar negeri. Mereka berlomba-lomba mendiskusikan NU secara panjang lebar dengan berbagai landasan epistemologis dan badkgaundpendidikan mereka masing-masing sehingga melahirkan sebuah karya berbentuk buku. KH. A. Wahid Hasyim menulis buku tentang Mengapa Merilih NU?: Konsepsi tertang Agama, Pendidikan, dan Pditik. D alam buku ini KH.A. Wahid pada awalnya mengamati bahwa NU adalah organisasi yang dipimpin oleh sekumpulan orang-orang tua yang pasti lamban bergerak, akan tetapi fakta yang terjadi bahwa NU di bawah kepemimpinan orang-orang tua tersebut dalam waktu 10 tahun sudah menyebar ke hampir seluruh Indonesia. Dia membandingkan dengan organisasi kepemudaan lainnya yang dalam kurun waktu 10 tahun juga hanya berdiri di dua karesidenan dan hanya tersebar di daerah itu-itu saja, dan karena itulah, dia memilih NU dalam berorganisasi (politik).

Martin van Bruiessen menulis buku yang berjudul NU: Tradisi, Rdasi Kuasa, Pencanian Wacana Banu terbit tahun 1994. D alam buku ini Bruiessen menceritakan tentang sejarah panjang NU sampai proses K hittah. Dia juga menjelaskan tentang problematika NU dalam bidang keagamaan, sosial, dan ekonomi. M. Ali Haidar menulis buku Nahdlatul Ulama' dan Isam Indonesia: Pendkkatan Fiqh dalam Pditik, terbit tahun 1994. Buku ini hadir seakan memberikan jawaban atas isu yang berkembang bahwa NU tidak konsisten dalam mengambil keputusan. M. Ali Haidar dalam buku ini menegaskan bahwa NU selalu konsisten dalam mengambil keputusan dengan qawa'id al-fiqhiyah yang selalu dipegang oleh $\mathrm{NU}$ dalam mengambil keputusan. Bahkan, masih banyak buku-buku yang ditulis oleh para pengamat dan pemerhati NU yang secara umum membedah keorganisasian NU dan pemikiran-pemikiran yang lahir darinya.

Akan tetapi diskursus tentang NU dari sisi teologi belum mendapatkan perhatian serius dari para pengamat dan peneliti. Padahal, teologi adalah salah satu disiplin keilmuan yang

${ }^{4}$ M. A. Sahal Mahfudz, Nuansa FiqhSosial (Yogyakarta: LKIS,1994), 189.

5Ilyas Ruhiyat et al., DinamikaKaumMuda, IPNU danTantanganMasaDepan(Jakarta: PP-IPNU), 1997, 39.

${ }^{6}$ K hotibul Umam Wirano, MerbacaUlangAswajadanUpaya Transformas PMII (Jakarta: PP-PMII), 1997. 
membahas tentang ajaran-ajaran dasar dari suatu agama, suatu ilmu yang akan mengantar pengkajinya pada keyakinan-keyakinan yang berdasarkan pada landasan yang kuat yang tidak mudah diombang-ambingkan oleh perubahan dan peredaran zaman, ${ }^{7}$ dan sekaligus melahirkan potensi gerakan dalam melaksankan iman, Islam dan ihsan ${ }^{8}$

Oleh karena itulah dalam tulisan ini, penulis akan memberikan perhatian lebih tentang konsep teologi yang dipegang kuat oleh NU, yaitu konsep Ahl al-Sumah wa al-Jama'gh yang

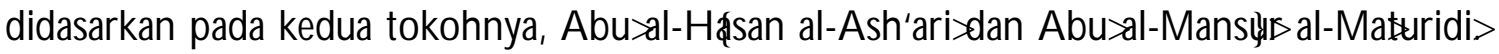
Pembahasan ini menjadi urgen untuk dikembangkan karena menurut pengakuan NU, konsep teologi selalu dirujuk kepada kedua tokoh tersebut. Hal ini juga tidak terlepas dari doktrin Ahl al-Sunnahnaal-Jama'dhyang menjadi fokus kajian tidak terlupakan dalam proses kaderisasi masyarakat NU. Harapan yang ingin dicapai adalah agar doktrin teologi Ahl al-Summah wa alJamałh tetap melekat dalam setiap pemikiran dan gerakan individu sebagai bagian dari masyarakat NU.

Proses kaderisasi konsep teologi Ahl al-Sumahwaal-Jama'ghinilah yang menjadi amanah dari hasil Munas dan Muktamar NU sehingga menghasilkan produk-produk berupa bukubuku pokok acuan dalam pengkaderan yang dilakukan NU terhadap anggota-anggota dan kadernya. Ada dua buku pengkaderan yang secara detail menjelaskan tentang konsep teologi Ahl al-Sunmah wa al-Jama'ah Petama, adalah "Konsep D asar Pengertian Ahl Sunnah wal Jama'ah" yang ditulis oleh KH. A hmad Masduqi. Buku ini diterbitkan oleh Pelita D unia, Surabaya tahun 1986 sebagai buku acuan pengkaderan di Jawa Timur. Keda, adalah "Konsepsi Ahl Sunnah wal Jama'ah" karya RS. Abdul Aziz yang diterbitkan oleh CV. Bahagia, Pekalongan, 1998, sebagai acuan pengkaderan di Jawa Tengah. Selain kedua buku pengkaderan ini, pengembangan konsep teologi $\mathrm{NU}$ dalam masyarakat luas masih dapat ditemukan dalam kitab-kitab teologi yang biasanya dikaji oleh di beberapa pesantren, sekolah diniyah, majlis ta'lim, dan forum diskusi atau ngaji lainnya. Kitab yang dimaksud adalah kitab 'Acicatal-A a wamdan al-Hxisunal-Hamidiyahyang sedemikian tersebar luas di masyarakat Indonesia pada umumnya, dan di warga NU pada khususnya.

D ari latar belakang inilah penulis ingin mengulas lebih dalam tentang relevansi konsep teologi yang dicita-citakan dalam Munas dan Muktamar NU yang meliputi konsep tentang ke-Esa-an Tuhan, ke-Qadiman al-Q ur'an, serta Qadk'> dan Qadar Tuhan yang didasarkan pada konsep teologi al-Ash'ari`dan al-Maturidiðlengan fakta yang terjadi di lapangan terkait proses pengkaderan $\mathrm{NU}$, baik yang dilakukan dalam organisasi-organisasi otonomnya, ${ }^{9}$ dalam pondok-pondok pesantren, maupun dalam gerakan pendidikan masyarakat NU, dengan dua buku panduan pengkaderan dan dua kitab yang dijadikan dasar sebagaimna dijelaskan sebelumnya.

\section{Teologi al-Ash'arixlan al-Maturidi>Cita-cita Teologi N U}

Sebagai basis teologi yang menjadi dasar pijakan oleh NU sebagaimna dicita-citakan dalam Munas dan Muktamar, Ahl al-Sunnah wa al-Jama'gh merupakan konsep teologi yang dianggap menjadi penengah dari "pertikaian alot" antara kaum salafi yang lebih menekankan

${ }^{7}$ Harun Nasution, Tedog Isam Aliran-aliranSgarahA nalisa Pedbandingan(Jakarta: UI Press, 1986), iv.

${ }^{8}$ Pengarus Nahdlatul Ulama' Cabang Surabaya, KdbangkitanUmat IdamdanPerananNU di Indonesa(Surabaya, t.p., 1980), 95 . 
pada otoritas nas\$jsebagai dasar pemikiran-pemikiran agama, dan Mu'tazilah yang lebih "mendewakan" akal dalam aplikasi interpretasi mass/ bahkan terkadang mendahulukan kekuatan akal dari pada menggunakan otoritas mass/ Tokoh penting yang berperan dalam pengembangan dan penyebaran paham ini adalah al-Ash'ari>dan al-Maturidi>

\section{1. al-Ash'ari>}

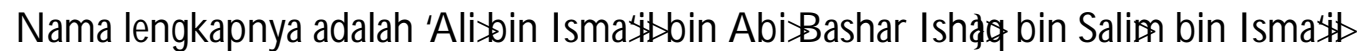

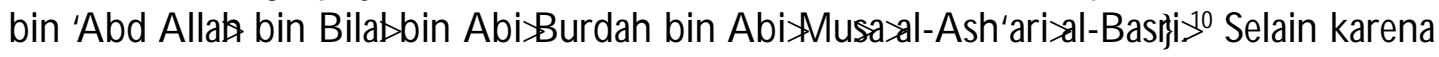
ada ikatan darah sebagai keturunan dari Abu»Musa>al-Ash'ari salah satu tokoh penting dalam proses tabkim gelar al-Ash'ari>disandarkan pada namanya karena dia berasal dari sebuah desa di Yaman yang bernama Ash'ar, yang konon ibunya lahir di desa tersebut. ${ }^{11}$

Menurut 'Abd Allah Shakis dan Fuqiyah H «sayn, al-Ash'ariłahir pada tahun 160 $\mathrm{H} .{ }^{12}$ Sedangkan mengenai kematiannya, para sejarawan tidak satu kata ketika menetapkan

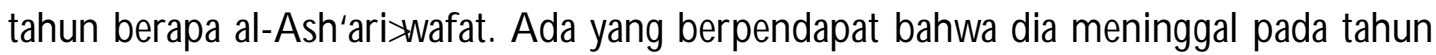
$324 \mathrm{H}$. A da juga yang mengatakan meninggal pada tahun $325 \mathrm{H}$. A dajuga yang mengatakan bahwa dia meninggal pada tahun $335 \mathrm{H}$. Akan tetapi jika merujuk pada muridnya, alBakili>al-Ash'arismeninggal pada tahun $324 \mathrm{H}^{13}$

Al-Ash'ari æadalah tokoh besar yang menguasi berbagai disiplin ilmu yang berbasis keagamaan. Dia ahli dalam bidang hạdith, tafsir, dan ilmu kalam (teologi). Keahliannya ini tidak terlepas dari pengaruh besar dari guru-gurunya sehingga menjadikannya sebagai tokoh multidisipliner. Di antara gurunya adalah seorang ahli hạdith bernama Zakariya> bin Yahya>al-Saji>(w. 285 H) yang sekaligus mengasuh al-Ash'ari>sepeninggal ayahnya ketika berumur dua tahun. ${ }^{14} \mathrm{G}$ uru yang lain adalah Abu $>$ K halifah al-Jahma> Sahal bin Nuh, Muhąmmad bin Ya'qub al-Maqri>'Abd al-Rahman Khalfi>al-D albi>dll. ${ }^{15}$

Al-Ash'ari>adalah salah satu ulama' yang produktif dalam bidang tulis menulis. Menurut 'Abd Allah Shakis Muhł̧mmad al-Jundi> dengan mengutip Ibn 'Asakir dan alZarkashi>mengatakan bahwa kitab yang ditulis oleh al-A sh'ari>mencapai 300 kitab, ${ }^{16}$ di

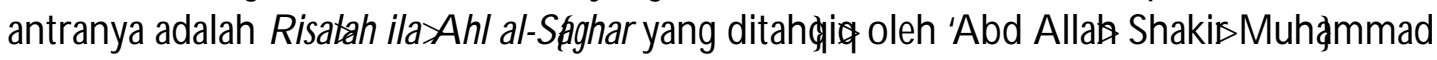

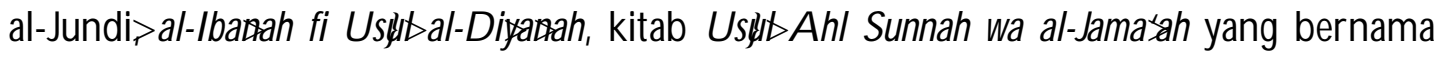

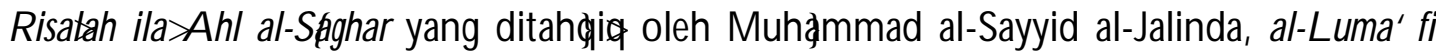
Radd 'alaYAh al-Zaygh wa al-Bida' yang ditahđiiq oleh Hamidah G harabah, dan lain-lain yang sebagian besarnya banyak membahas tentang teologi. Walaupun pada awalnya alAsh'ari>adalah pengikut Mu'tazilah bahkan pernah menjadi salah satu tokohnya, akan

\footnotetext{
${ }^{9}$ Bagian dari organisasi otonom NU terdiri dari: Ma'arif, ekonomi, dakwah, muslimat, Pertanu, dan lain-lain. termasuk juga bagian otonomnya adalah GP Anshor, IPNU, dan IPPNU. Lihat Endklopedi Indonesia, jil. 4, 23272328.

${ }^{10} \mathrm{Abu}$ al-H assan al-A sh'ari> Risalah ila>Ahl al-Saghar, tahłqiø 'Abd Allah Shakir Muhł̧mmad al-Jundi> (Madinah:Maktabat al-'Ulum wa al-Høk km, 1988), 33.

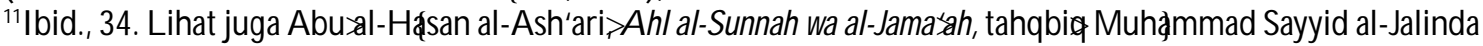
(Mesir: Universitas Kairo, t.th.), 5.

${ }^{12}$ Abdullah Syakir Muhammad, Risalah, 37-38. Lihat juga dalam Abusal-H Diyamah, tahłig Fuqiyah H «lsayn Mahignud (Kairo: Universitas 'Ain al-Sham, 1998), 13-14.

${ }^{13}$ Ibid., 37.

${ }^{14}$ Ibid.

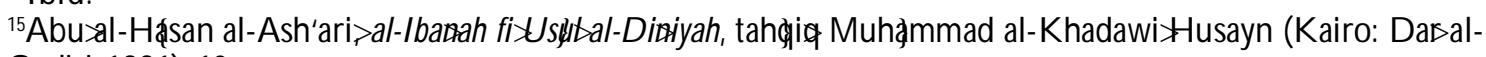
Qadiri>1991), 10.

${ }^{16}$ Abdullah Syakir Muhammad, Risalah, 47.
} 
tetapi beberapa kitab yang ditulisnya ini lalu dijadikan dasar teologi yang selanjutnya disebut dengan konsep teologi Ahl al-Sumah wa al-Jama'gh

D engan berbekal beberapa kitab inilah penulis akan mengkaji tiga pembahasan penting yang menjadi fokus penulisan ini, yaitu mengenai ke-Esa-an tuhan, ke-Qadman al-Q ur'an, dan Qadł'’ Qadar Tuhan.

a. Ke-Esa-an Tuhan

Hampir semua ulama' termasuk al-Ash'ari sepakat bahwa Allah adalah Tuhan yang Maha Esa. Akan tetapi kajian definitif mengenai ke-Esa-an Tuhan seringkali mengalami perbedaan pendapat di antara mereka. Tentang ke-Esa-an Tuhan ini alAsh'ari berhujjah dengan terciptanya alam semesta dari tidak ada menjadi ada, yang mana pasti diciptakan oleh Tuhan yang Maha Esa, Maha Tahu, Maha Kuasa, Maha Berkehendak, Maha Berbicara, Maha Mendengar, dan Maha Melihat. ${ }^{17}$

Sepintas pernyataan ini berimplikasi pada pernyataan bahwa Allah mempunyai beberapa sifat yang konsekuensi logisnya adalah akan berkumpul dzat dan sifat tuhan pada eksistensi tuhan sendiri. D engan bahasa lain akan muncul istilah ta'addal-qudama'? Oleh karena itu, al-Ash'ari>menegaskan bahwa sifat-sifat tuhan ini bukanlah Tuhan dan bukan selain Tuhan (lałhiya huma wa lałiya ghaynuhur. Sifat-sifat Tuhan tidak sedikitpun mengurangi kesempurnaan tuhan. Alasan logisnya adalah bahwa sifat-sifat Tuhan tidak sama dengan sifat yang melekat pada makhluqNya, berikut juga dzat Tuhan sangat berbeda dengan semua ciptaannya yang sifatnya baru. ${ }^{18} \mathrm{D}$ i samping itu, al-Ash'ariðdalam menyikapi ayat-ayat mitashakihatyang berkaitan dengan wajah Tuhan, tangan Tuhan, dan mata Tuhan tidak mena'wil sebagaimna yang dilakukan kalangan al-Mu'tazilah. Al-Ash'ariłebih mempertahankan makna aslinya dengan menjadikannya sebagai sifat "bila`kayfa", sifat-sifat yang tidak perlu dirasionalisasikan dan dita'wil lebih jauh. ${ }^{19}$

Oleh karena itu, menurut al-Ash'ari>Tuhan adalah zat yang Maha Esa dengan sifat-sifat sebagai berikut: 1) Wijud (nafsijah), 2) Qadiran, Muridan, 'Aliman, Hayyan, Sami'an, Basitan, dan Mutakalliman (disebut dengan sifat Ma'ari), 3) Qudrah, Irackh, 'Tlm Hayah, Sama', Basar, dan Kalam(disebut sifat Mánawiyah), 4) Wajhun Yadun, Ayn (disebut sifat bi laЖaya)

b. Ke-Qadiman al-Qur'an

Al-Ash'ari>menegaskan bahwa al-Q ur'an itu adalah kalam Allah. Sedangkan kalam Allah adalah cadim Oleh karenanya al-Qur'an bukanlah makhluq. Pendapat ini sekaligus mengkritik habis-habisan pendapat yang berbeda dari Mu'tazilah bahwa al-Q ur'an itu adalah makhluq. D ia memberi alasan bahwa "ketika Tuhan menghendaki sesuatu, kemudian berkata kun fa yakun atau kuri łorrdan wa salannan kepada api, maka kalam Tuhan di sini bukanlah kunatau kuri karena keduanya ditujukan kepada sesuatu. Sedangkan kalam Tuhan adalah al-Qur'an itu sendiri yang juga merupakan sifat-sifat tuhan. Sedangkan sifat Tuhan adalah Qadim ${ }^{20}$ Alasan lainnya menurut al-A sh'ari>semua

\footnotetext{
${ }^{17} \mathrm{~A}$ bu xal-H assan al-A sh'ari>Ahl al-Sunnahnal Jama'ah 65.

${ }^{18} \mathrm{~A}$ bu $a l-\mathrm{H}$ qsan al-A sh'ari>RisalahilaA hl al-Saghar, 216-217.

${ }^{19} \mathrm{~A}$ bu rl-H $\mathrm{H}$ san al-Ash'ari>Ahl al-Summahwal Jama'ah 75-76.

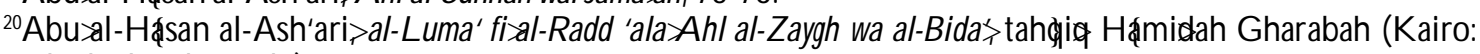
Maktab al-Azhas, t.th.), 33-35.
} 
nama-nama Tuhan secara tegas disebutkan dalam al-Qur'an. Paham teologi al-Ash'ari> menegaskan bahwa nama-nama tersebut adalah Qadimdan bukan makhluq.

c. Qadł'’' dan Qadar Tuhan

Pada dasarnya Qadł’ dan Qadar adalah salah satu dari rukun iman yang 6 sebagaimana dijelaskan oleh malaikat Jibril ketika bertemu dengna Nabi. Menurut alAsh'ari> Qadł’’ dan Qadar adalah suatu keniscayaan dari Allah yang harus diimani secara mendalam oleh semua umat Islam, baik berupa kebaikan yang diperintahkan untuk dikerjakan, ataupun keburukan yang dilarang untuk dilakukan. ${ }^{21}$

Hal menarik yang perlu dicermati di sini, al-Ash'ari>berpendapat bahwa Allah menciptakan baik dan buruk untuk manusia dan semua makhluqNya. Akan tetapi dia menegaskan bahwa keburukan adalah hasil perbuatan penciptaan Tuhan dan seluruh keburukan itu dilarang oleh Tuhan dan harus dijauhi. Sedangkan kebaikan itu adalah perintah Tuhan dan dianjurkan untuk melakukannya. ${ }^{22}$

\section{2. al-Maturidi>}

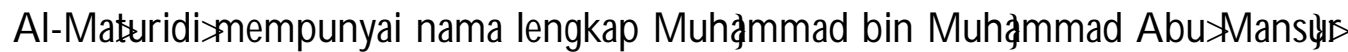
al-Maturidi>al-Samarqandi>al-Ansł̧rił³ D juluki A bu>al-Mansłłı karena dia mempunyai anak laki-laki bernama al-Mansłłr. Sedangkan gelar al-Maturidi>dikarenakan dia lahir di daerah Maturid, dan al-Samarqandi karena Maturid tempat kelahirannya berada di wilayah Samarcand. Pada tahun $248 \mathrm{H}$ al-Maturidi`lahir , dan tahun $333 \mathrm{H}$ dia meninggal. ${ }^{24}$

Di belakang kesuksesan al-Maturidi×sebagai tokoh besar khususnya dalam bidang teologi tidak terlepas dari jasa-jasa gurunya yang selalu membimbingnya. Silsilah gurunya bisa dijelaskan sebagai berikut. Pada awalnya al-Maturidi`berguru kepada Abu>Nasir alIyadi> lalu ke Abu>Bakar Muhłmmad al-Jawzi> lalu ke Abu>Sulayman al-Jawzi> ke

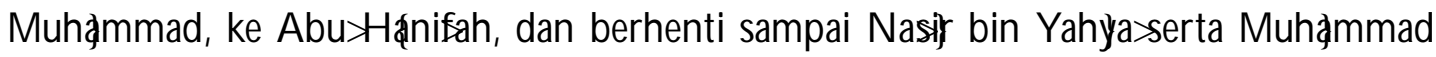
bin Maqatill bin al-Razi $2^{5}$

Sebagai tokoh agama yang multidisipliner, al-Maturidi>mempunyai banyak kitab yang ditulisnya sebagai aktualisasi dari keilmuan yang dia miliki. Di antara kitabnya adalah al-Jidal, Ma'khadal-Shani'ah (dua kitab uslilsal-fiqhyang bercorak H ג̇nafił, Ta'vilat al-Quran (Ta'wil>Ahl al-Sunnah), Risalıh fi»mała>Yajuz al-Waqf fih al-Quran al-Kanim Shambal-Fiqh al-Akbar, dan al-A qidah ${ }^{26}$

Secara umum, corak pemikiran teologi al-Maturidi>adalah penengah antara menggunakan akal dan naq dalam penetapan ajaran agama sebagai penengah antara alMaturidi>dan Salaf dalam pemikiran teologi. Oleh karena itu, al-Maturidiðdikenal sebagai tokoh Ahl al-Sumah wa al-Jama'ghyang sangat paham terhadap ajaran agama baik dengan akal maupun naql. Maka, tidak jarang dia lebih rasional dalam menjabarkan konsep teologinya dibandingkan dengan al-Ash'ari ${ }^{7}$

${ }^{21}$ Ibid., 122-123.

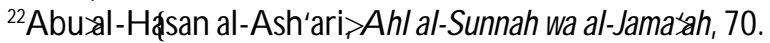

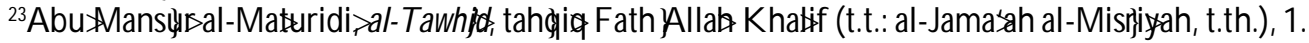

${ }^{24}$ Ibid., 2.

${ }^{25}$ Aliæy Abd al-Fattah al-Maghrabi>ImamA hl al-Sunnahwaal-Jama'ah(t.t.: Maktabah Wahbah, 1989), 18-19.

${ }^{26} \mathrm{Abu}$ Manslit:al-Maturidi>al-Tawhid 22-29.

${ }^{27} \mathrm{~A}$ li`A bd al-Fattah al-Maghrabi>ImamAhl al-Sunnah, 31. 
Menurut al-Maturidi> untuk mengetahui ajaran agama diperlukan dua alat yang sangat urgen untuk digunakan, yaitu pendengaran (al-sima') dan akal (al-'ad), walaupun batas pengetahuannya hanya pada ruang lingkup yang global tanpa mendalami lebih jauh penjelasan secara hakiki dan spesifik. Untuk penjelasan secara hakiki dan spesifik, maka manusia perlu menggunakan daya rasa, berita, dan renungan. Berikut penjelasan lebih jauh tentang konsep teologi al-Maturidi>

a. Ke-Esa-an Tuhan

Allah adalah Tuhan yang Maha Esa. Untuk membuktikan ke-Esa-an Tuhan ini al-Maturidimmemberikan alasan dengan terciptanya alam semesta, yang pasti diciptakan oleh Tuhan yang Maha Esa. Secara pendengaran yang diperoleh dari al-Q ur'an sudah pasti menunjukkan bahwa Tuhan Maha Esa. Sedangkan jika dirasionalisasikan dengan akal, maka kesimpulannya pun sama, Tuhan adalah Maha Esa. Andaikan alam diciptakan oleh dua Tuhan yang masing-masing dari keduanya mempunyai kehendak yang berbeda, maka alam ini akan rusak dan hancur. Jika kehendaknya sama, maka berarti Tuhan bukanlah zat yang Maha Kuasa. Oleh karena itu, Tuhan pasti Maha $\mathrm{Esa}^{28}$

Walaupun Tuhan adalah Maha Esa, ini bukan berarti Tuhan tidak memiliki sifat. Menurut al-Maturidi> Allah mempunyai sifat-sifat yang Qadim sebagai berikut: 1) Nafsiyah (berupa wujud), 2) Ma'arił Qadiran, Muridan, Hayyan, Sami'an, Basikan, dan Mutakalliman), 3) Mánawiyah (Qudrah, Iradah, 'Tlm Hayah, Sama', Basar, dan Kalam), 4) Dhatiyah (berupa tangan, wajah, dan mata). ${ }^{29}$

b. Ke-Qadiman al-Qur'an

Al-Q ur'an adalah Kalam Allah. Sedangkan Kalam Allah adalah Qadim sebagaimana zatNya. Oleh karena itu, al-Q ur'an yang merupakan Kalam Allah yang Qadimini bukanlah makhluk sebagaimana dinyatakan oleh kaum Mu'tazilah.

Menurut al-Maturidi>untuk mengetahui ke-Qadiman al-Q ur'an, maka diperlukan pendengaran dan akal. Pendengaran diperoleh melalui banyak media termasuk dari penjelasan al-Q ur'an. Untuk mengetahui kebenaran yang diperoleh dari pendengaran, maka akal mempunyai peranan penting, karena mampu mengetahui baik dan buruknya sesuatu. ${ }^{30}$ Sedangkan untuk mengetahui lebih dalam tentang ke-Qadman al-Q ur'an, maka diperlukan media rasa, berita, dan berfikir.

Termasuk bukti ke-Qadiman al-Qur'an adalah adanya kemukjizatan yang ada pada diri al-Q ur'an, di mana seluruh manusia dan makhluq Tuhan lainnya tidak mampu mengarang sebuah karya seperti al-Q ur'an walaupun hanya satu ayat, dan tantangan ini berlaku sampai akhir dunia, bahkan sampai sekarang terbukti belum ada satu pun yang mampu melakukannya. ${ }^{31}$

c. Qadk'>dan Qadar Tuhan

Qadápdan Qadar Tuhan adalah salah satu dari rukun iman yang wajib diimani

\footnotetext{
${ }^{28} \mathrm{Abu}$ Manslypal-Maturidi;al-Tanhild 44

${ }^{29}$ Inilah yang membedakan al-Maturidi`dan al-Ash'ari>Sifat tangan, wajah, dan mata disebut dhatiyaholeh alMaturidi>dan disebut bilałaifa oleh al-Ash'ari>Ibid., 12.

30Tbid., 4.

${ }^{31}$ Ibid., 44.
} 
oleh seluruh umat Islam. Menurut al-Maturidi>Qadḱa ${ }^{\prime}$ adalah keputusan Tuhan terhadap sesuatu dan dipastikan bahwa keputusan itu pantas baginya. Hikmah dari adanya Qadj’ adalah tercapainya hakikat bagi segala sesuatu yang diciptakan dalam memerankannya sesuai dengan peranannya. Sedangkan Qadar adalah ukuran tentang baik dan buruk. Oleh karena itu, ukuran tersebut merupakan sebuah keniscayaan yang pasti terjadi dan tidak akan bisa keluar dari ukuran tersebut. ${ }^{32}$ Hakikat dari mengimani Qada' dan Qadar menurut al-Maturidi>adalah mengimani dan meyakini kepada semua ketentuan dan keputusan Tuhan dengan segala keniscayaannya yang melekat pada keputusan tersebut, termasuk juga batas dan ukuran Tuhan tentang baik dan buruk, keterangan tentang hak dan batil, serta konsekuensi berupa pahala dan dosa.

\section{Teologi NU dalam Kadenisasi dan Pendidikan}

Konsep teologi al-Ash'ariædan al-Maturidi>sebagaimana dipaparkan pada bagian awal, merupakan cita-cita agung dari Munas dan Muktamar NU dalam bidang teologi. Namun demikian, bagaimana praktiknya dalam proses kaderisasi dan pendidikan di NU, apakah sesuai dengan cita-cita awal ataukah ada beberapa konsep yang perlu dibenahi karena dianggap tidak sesuai dengan konsep teologi al-Ash'ari>dan al-Maturidi>

1. Konsep Teologi NU pada Proses Kaderisasi

Pengurus NU mempunyai buku pokok yang digunakan sebagai acuan pada proses pengkaderan NU terhadap anggota dan kadernya. Ada dua buku pengkaderan yang secara detail menjelaskan tentang konsep teologi Ahl al-Sumah wa al-Jamágh Petama, adalah Konsep Dasar Pengetian Ahl Surnah wal Jama'ah yang ditulis oleh KH. A hmad Masduqi. Buku ini diterbitkan oleh Pelita D unia, Surabaya tahun 1986 sebagai buku acuan pengkaderan di Jawa Timur. Kedua, adalah Konsepi Ah Sumah wal Jama'ah karya RS. Abdul Aziz yang diterbitkan oleh CV. Bahagia, Pekalongan, 1998, sebagai acuan pengkaderan di Jawa Tengah. Dua buku ini secara konkret menjelaskan konsep teologi yang berkaitan dengan ke-Esa-an Tuhan, ke-Qadiman al-Q ur'an, serta Qadá'dan Qadar Tuhan.

a. Ke-Esa-an Tuhan

D alam buku pengkaderan Jawa Timur dan Jawa Tengah dijelaskan bahwa Tuhan adalah Maha Esa, dan dan ke-Esa-an Tuhan ini mempunyai sifat-sifat yang cadimdan Maha Sempurna. ${ }^{33}$ Walaupun sama dalam prinsip ke-Esa-an Tuhan, akan tetapi dua buku ini memuat dua perbedaan, yaitu: petama, dalam buku pengkaderan Jawa Timur dijelaskan bahwa sifat-sifat Tuhan ada 13, yaitu Wujud(disebut Nafsiyah), Qidam Baqa's Mukhalafatuh li al-Havadth, Qiyamin bi Nafsih, Wahdariyah (disebut Salbiyah), Qadiran, Muridan, 'Aliman, Hajyan, Sami'an, Basirean, dan Mutakalliman (disebut Ma'nawiyah). Sedangkan menurut buku pengkaderan Jawa Tengah, sifat-sifat Tuhan ada 20, yaitu: Wujud (disebut Nafsijah), Qidam, Baca', Mukhalafatuh li al-Häwadith, Qiyamuh bi Nafsih,

\footnotetext{
32Ibid., 305-306.

${ }^{33}$ Ahmad Masduqi, KonsepDasar PengetianAhl Sumnah wal Jama'ah(Surabaya: Pelita dunia, 1986), 39. Lihat juga dalam RS. Abdul Aziz, Konsepsi Ahl Sunnahwal Jama’ah(Pekalongan: CV. Bahagia, 1998), 97.
} 


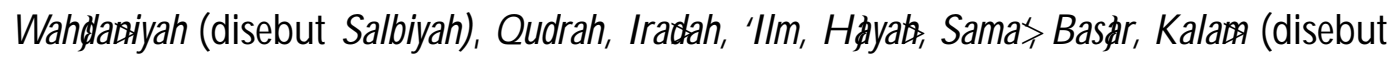
Máari), Qadiran, Muridan, 'Aliman, Hajyjan, Sami'an, Basikran, dan Mutakalliman (disebut Ma'naniyah), dan kedua, adalah dari segi rasionalisasi sifat-sifat Tuhan. Buku pengkaderan Jawa Tengah lebih panjang lebar penjelasannya dibandingkan buku pengkaderan Jawa Timur.

b. Ke-Qadiman al-Qur'an

Semua kitab-kitab yang diturunkan Allah kepada NabiNya, termasuk al-Q ur'an, adalah Kalam Allah yang wajib diimani dan diyakini. ${ }^{34} \mathrm{~K}$ arena al-Q ur'an adalah Kalam Allah, maka konsekuensi logisnya adalah al-Q ur'an adalah Qadim Bukti ke-Qadiman al-Q ur'an adalah kemukjizatan yang terdapat dalam al-Qur'an sehingga tidak satu pun manusia yang mampu menciptakan apalagi menandingi kehebatan al-Qur'an. ${ }^{35}$ Di samping itu, dalam al-Qur'an terdapat arahan dan tuntunan bagi semua umat manusia untuk menggapai kebahagiaan di dunia dan akhirat. Inilah yang membuktikan bahwa al-Q ur'an itu Qadim

c. Qadä'>dan Qadar Tuhan.

D alam buku pengkaderan Jawa Timur dijelaskan bahwa mengimani Qadás'dan Qadar adalah suatu kewajiban bagi semua umat Islam dengan carfa meyakini bahwa Tuhan telah menetapkan kebaikan dan keburukan sebelum Tuhan menciptakan makhluq. Oleh karena itu, seluruh apapun yang telah terjadi, sedang terjadi, ataupun akan terjadi tidak terlepas dari Qadá’dan QadarTuhan, baik berupa hal yang baik dan bermanfaat bagi makhluq, ataupun berupa keburukan yang mengkibatkan kesengsaraan bagi makhluq. ${ }^{36}$

Agak berbeda dengan di Jawa Timur, dalam buku pengkaderan Jawa Tengah dijelaskan bahwa Qadä’adalah ketentuan dan ketetapan Tuhan pada zaman azali. Sedangkan Qadar adalah ketentuan Tuhan yang harus niscaya di dunia yang akan terjadi pada makhluq hidup dan mati, baik berupa kebaikan ataupun keburukan. Namun yang membedakan adalah manusia tetap mempunyai usaha (ikhtiyars) tanpa menunggu QadarTuhan. Oleh karenanya, Qadád'dan QadarTuhan bisa berubah dengan usaha (ikhtiyar) dan doa manusia, walaupun keduanya (usaha dan doa) itu adalah bagian dari ketetepan Tuhan juga. ${ }^{37}$

\section{Teologi NU di Tingkat Pendidikan}

NU telah melakukan proses kaderisasi kepada anggota dan kadernya dengan cara internalisasi teologi Ahl al-Sumnah wa al-Jama'gh dengan media buku-buku pengkaderan. Tidak berhenti di sana, proses internalisasi ini terus berlanjut di tingkat pendidikan formal maupun informal, baik di pengajian-pengajian, majlis ta'lim, pesantren, dan forum lainnya. Sebagai acuan, forum ini biasanya menggunakan salah satu dari dua kitab yang sudah terkenal di kalangan masyarakat NU, yaitu kitab Aqidatal-'Anam karya A hmad al-Marzuki>

\footnotetext{
${ }^{34} \mathrm{~A}$ hmad Masduqi, KonæepDasar, 41.

${ }^{35}$ RS. Abdul Aziz, Konsqpsi, 15.

${ }^{36} \mathrm{~A}$ hmad Masduqi, KonsppDasar, 43.

${ }^{37} \mathrm{RS}$. Abdul Aziz, Konsqpi, 54.
} 
dan al-Hzksun al-Hamidiyah karya Husein Afandi al-Jisr al-Tharabulusi dan ditashibjoleh Ridwan Muhammad Ridwan. Dua kitab ini memberikan deskripsi yang lugas tentang teologi $\mathrm{Ah}$ al-Sumah wa al-Jama'ah khususnya yang berkaitan dengan ke-Esa-an Tuhan, ke-Qadiman al-Q ur'an, serta Qadk's'dan Qadar Tuhan.

a. Ke-Esa-an Tuhan

Allah adalah Tuhan Yang Maha Esa. Ke-Esa-an Tuhan ini mempunyai sifatsifat yang melekat pada diriNya, dan berbeda dengan selainNya tanpa ada kemiripan sedikitpun. Menurut al-Marzuki, sifat Tuhan dibagi menjadi 4, yaitu 1) Nafsiyah yaitu uxjud, artinya adalah Allah benar-benar ada, 2) Salbiyah, artinya adalah Tuhan tidak pantas disifati dengan sifat-sifat sebaliknya. Sifat salbiyah ada 5, Qidam Baqa',

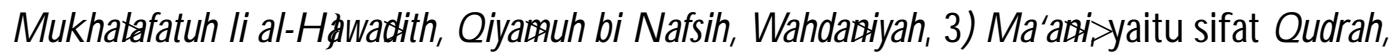
Iradah, Tlm Hajyah Samas, Basar, Kalam dan 4) Ma'nauiyah artinya berintegrasinya sifat-sifat máari xlengan zat Tuhan..$^{38}$

Sedangkan menurut Husein Afandi dalam kitab al-Husum al-Hłamidiyah menjelaskan bahwa mempercayai ke-Esa-an Tuhan adalah sebagian dari iman, dan ke-Esa-an Tuhan ini tidak terlepas dari sifat-sifat Tuhan yang 13, yaitu Wujud, Qidam

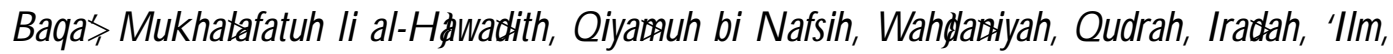
Hżyah, Sama', Bas\}ar, Kalam ${ }^{39}$ Bedanya dengan kitab 'Aqieat al-Awamadalah Husein Afandi tidak membagi sifat-sifat Tuhan ini menjadi Nafsiyah, Salbiyah, Máarii>dan Ma'namiyahsebagaimana ditulis dalam 'Aqidat al-'A vam Husein Afandi mengeneralisasi semua sifat Tuhan dan menegaskan bahwa seluruh sifat Tuhan tersebut menyatu dalam zat-Nya (qaim bi dhatih).

b. Ke-Qadiman al-Qur'an

D alam 'Aqidat al-Awam ditegaskan bahwa al-Qur'an adalah Kalam Allah tanpa ada sedikitpun yang berasal dari manusia, termasuk Nabi Muhammad dan Malaikat Jibril. Oleh karenanya, semua lafaz/dan máma>al-Qur'an berasal dari Allah semata. ${ }^{40}$ Sangat berbeda dengan perkataan makhluq, K alam Tuhan adalah sifat yang azali sesuai dengan dhat-Nya, dan diturunkan kepada Nabi Muhammad tanpa media hurf ataupun suara (bi lasharf wa lassant). Sedangkan al-Q ur'an yang dapat dibaca, ditulis, dan diperdengarkan adalah Kalam Tuhan yang berupa lafaz)(ucapan) yang menunjukkan kepada arti yang abadi (qadim). ${ }^{41}$

Menurut Husein Afandi, Kalam Tuhan mempunyai dua makna, petama, Kalam Tuhan adalah sifat Tuhan yang abadi karena dhat Nya yang bukan berupa huruf dan suara, dan kedua, Kalam Tuhan adalah kalam yang berupa lafaz,yang diturunkan kepada Rasul. ${ }^{42}$ Untuk membuktikan ke-Qadiman al-Q ur'an, Husein Afandi berargumentasi dengan adanya cerita-cerita dan sejarah masa lampau yang dijelaskan di dalam alQur'an seperti sejarah para Nabi dan Rasul. Bukti yang lain adalah kemukjizatan alQur'an yang tidak mampu ditandingi oleh semua makhluq di muka bumi ini dari dulu

\footnotetext{
${ }^{38}$ Muhł̆mmad bin 'Aliłoin Muhł̆mmad Ba'athiyah al-D a'uani>Mujizal-Kalam(Surabaya: t.p., 2009), 53.

${ }^{39}$ Lebih lengkap mengenai sifat-sifat Tuhan beserta bukti-bukti kebenaran sifat tersbut, lihat Husein Afandi al-Jisr al-T harabulusi, al-Hisunal-Hamidijah(Surabaya: t.p., 1970), 14-17.

${ }^{40}$ Muhammad bin Aliøin Muhammad Ba’athiyah al-D a'uani>Mujizal-Kalam 119.

${ }^{41}$ Ibid., 89.

${ }^{42}$ Husein Afandi al-Jisr al-Tharabulusi, al-Hx́sunal-Hamidiyah 124.
} 
sampai sekarang.

c. Qadk'> dan Qadar Tuhan

Qadk's dan Qadar Tuhan adalah salah satu rukun iman. Esensi mengimaninya adalah dengan cara meyakini bahwa semua yang terjadi di dunia adalah copy pastedari suatu ketentuan yang telah ditaqdirkan Tuhan sebelum terciptanya alam, dan Allah adalah dhatyang mengetahui semuanya secara detail.

Tuhan telah menciptakan kebaikan dan keburukan untuk manusia agar bisa memilih, yang tentunya mempunyai konsekuensi dari masing-masing keduanya. Jika memilih perbuatan buruk, maka dia harus bertaubat sepenuhnya sehingga bisa terlepas dari dosa-dosa, jika tidak, maka dia berhak disiksa dengan siksaan yang pedih. Sebaliknya, jika manusia lebih memilih perbuatan baik, maka dia berhak mendapatkan satu tempat di surga sebagai konsekuensi logis dari pilihannya. ${ }^{43}$

Sedangkan menurut Husein Afandi, QadarTuhan adalah ketentuan Tuhan pada zaman azali»erhadap ukuran yang akan terjadi kepada makhluq, baik berupa kebaikan ataupun keburukan. Sedangkan Qadá’adalah pelaksanaan Tuhan terhadap semua ukuran yang sudah terplaning pada zaman azali $\$^{4}$ O leh karena itu, Qadk'>dan Qadars Tuhan, yang merupakan program-program Tuhan pada zaman azaliłengkap dengan ketentuan pelaksanaan dan rincian teknisnya, wajib diimani oleh semua umat Islam tanpa terkecuali. Mengingkari eksistensi Qadä’dan Qadar akan mengantarkannya pada sebuah ke-kafir-an.

\section{Genealogi Teologi NU}

NU mempunyai seperangkat aturan yang dilahirkan dari Munas dan Muktamar yang memang rutin dilakukan untuk selalu meneguhkan eksistensi diri dan menyempurnakan kekurangan-kekurangan yang selama ini masih menjadi titik celah bagi internal NU sendiri. Sebagaimana dijelaskan sebelumnya, $\mathrm{NU}$ adalah organisai Islam yang berhaluan Ahl al-Sumah wa al-Jamałah D alam bidang teologi, mendasarkan dirinya kepada Abu>al-H dan Abu>al-Manshlas al-Maturidi>D alam bidang fikih, bermazhab pada pada salah satu dari

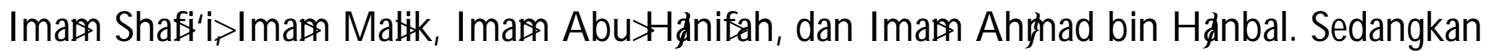
dalam urusan tasawuf, NU berkiblat pada tasawuf al-G azalìdan Junayd al-Baghdadis

Oleh karena itu, dalam bidang teologi, NU selalu mendasarkan dirinya kepada konsep teologi yang dimotori oleh al-A sh'ari dan al-Maturidi yang bernama ahl Ahl al-Sumnah wa alJama'gh khusunya dalam bidang ke-Esa-an dan sifat-sifat Tuhan, Kalam Tuhan dan hubungan antara akal dan wahyu, serta kehendak manusia yang berkaitan dengan Qadk'’dan Qadar Tuhan.

a. Ke-Esa-an Tuhan dan Sifat-sifatNya

Berbicara tentang sifat-sifat Tuhan, al-A sh'ariłlan al-Maturidisepakat bahwa Tuhan adalah Maha Esa, dan dalam ke-Esa-an-Nya Tuhan mempunyai sifat-sifat yang Qadim Dalam merasionalisasikannya pun keduanya menggunakan bukti-bukti logis sehingga

\footnotetext{
${ }^{43}$ Muhammad bin A liøin Muhammad Ba'athiyah al-D a'uani>Mujizzal-Kalam 85. ${ }^{44}$ Husein Afandi al-Jisr al-Tharabulusi, al-Hrisunal-Hæamidiyah 26.

${ }^{45}$ Pengurus Wilayah NU Jatim, KeputusanMuktamar NUXXV II (Surabaya: Pengurus Wilayah NU Jatim, 1984), 77-78. Lihatjuga PBNU, KeputusanMunasAlimUlama' danKonbesNUdi BandarLampung(Jakarta: PBNU, 1992), 128.
} 
tidak ada satupun yang menyangkal ke-Esa-anNya. Oleh karena itulah walaupun keduanya termasuk tokoh yang berpegang teguh pada teks, akan tetapi yang menjadikan nilai lebih bagi mereka adalah keduanya berusaha merasionalisasikannya dengan media akal, walaupun al-Maturidiłmelebihi al-Ash'ariælari segi sistematisasi dalam berpikir karena menggunakan pendengaran dan akal dalam mengakses kebenaran agama secara global, kemudian merincinya melalui daya rasa, berita, dan berpikir lebih dalam.

Ada beberapa hal yang membedakan antara al-A sh'arizlan al-Maturidi>Selain jumlah sifat yang berbeda, yaitu menurut al-Maturidi>ada sifat Salkiyah sedangkan al-A sh'ari> tidak membahas tentang sifat Salkiyah, antara keduanya memiliki perbedaan dalam memberikan status pada sifat-sifat Tuhan tersebut. Baik al-A sh'ari>maupun al-Maturidi> sama-sama sepakat bahwa Allah mempunyai sifat tangan, wajah, dan mata. Bedanya, jika al-Ash'ari`menegaskan bahwa ketiga sifat tersebut adalah sifat bi lakayf (tidak perlu dipertanyakan lagi), sedangkan sifat yang lain bukan, maka al-Maturidimenjelaskan bahwa semua sifat-sifat Tuhan yang terdiri dari nafsiyah, salbiyah, máari;dan mánaviyahmerupakan sifat Tuhan yang bi lakayf karena menunju kepada bentuk, sedangkan Tuhan tidaklah berbentuk.

Konsep teologi tentang ke-Esa-an Tuhan dan sifat-sifat yang dikawal oleh al-Ash'ari> dan al-Maturidi>inilah yang pada awalnya menjadi cita-cita NU dalam Munas dan Mukatamar. Ketika melihat fakta yang terjadi di lapangan dalam proses kaderisasi dan pendidikan NU, ada hubungan yang sangat dekat antara cita-cita dan fakta yang terjadi, walaupun dalam beberapa bidang belum maksimal dan perlu diperbaiki. Konkretnya, dalam buku pengkaderan NU Jawa Timur, walaupun secara umum memiliki kecocokan dengan konsep teologi Ahl al-Sumah wa al-Jama'gh versi al-'Ash'ariðdan al-Maturidi>akan tetapi tidak menyebutkan sifat ma'ari Łanpa ada alasan yang jelas.

Kemudian, baik dalam buku pengkaderan NU Jawa Timur ataupun Jawa Tengah, keduanya tidak membahas tentang sifat Tuhan berupa tangan, wajah, dan mata. Walaupun dari sisi rasionalitas, buku pengkaderan NU Jawa Tengah memiliki nilai lebih dari pada Jawa Timur karena memberikan porsi yang cukup banyak dalam menjelaskan sifat-sifat Tuhan berikut bukti konkretnya.

Kurangnya rasionalisasi terhadap sifat-sifat Tuhan ini juga berlaku dalam kitab 'Aqidat al-A wam Hal ini bisa dimaklumi karena objek kitab ini biasanya ditujukan kepada siswa ibtida'yah (tingkat SD ). Hal yang berbeda adalah jika mengaca pada penjelasan Husein Afandi dalam kitab al-Hzsun al-Hamidyah D ia menjelaskan secara panjang lebar tentang bukti-bukti sifat-sifat Tuhan. Bahkan dia menambahkan bahwa semua umat Islam harus mengetahui sifat-sifat Tuhan baik yang wajib, mustahil, maupun jaiz Pemahaman tersebut akan mudah didapatkan dengan cara mengerti tentang hukum-hukum akal, yaitu wajib 'adi>>mstahil 'adii>dan jaiz 'aqi>

b. Mengenai Kalam Allah dan interaksi antara wahyu dan akal

Sebagai pioner dari paham Ahl al-Sumah wa al-Jama'ah al-Ash'ari>dan al-Maturidi> sepakat bahwa al-Qur'an adalah Kalam Allah dan bersifat Qadim Lalu, dengan media apakah manusia bisa mengetahui bahwa al-Q ur'an adalah Kalam Allah dan bersifat Qadir? Al-Ash'ariæmenjelaskan bahwa hanya dengan akallah manusia bisa mengetahuinya. Akal manusia merupakan anugerah Tuhan sehingga mampu mengetahui segala sesuatu yang 
diberitakan Allah dan RasulNya.

Al-Maturidi menambahkan, untuk mengetahuinya tidak cukup dengan akal semata. Media yang mampu mengetahui al-Q ur'an adalah melalui pendengaran dan akal, walaupun pengetahuan yang diperoleh hanya bersifat global. Melalui keduanya (akal dan pendengaran) manusia mampu memahami kebenaran dan keburukan yang dijelaskan oleh al-Q ur'an secara global. Untuk mengetahui lebih rinci dari kebenaran dan keburukan yang hakiki, maka manusia mempunyai media tambahan berupa indera, khabar, dan berpikir. D ialektika berpikir dari konsep teologi inilah yang menjadi cita-cita NU dalam Munas dan Muktamar. Hal yang menggembirakan adalah ketika cita-cita itu mempunyai kecocokan dengan fakta yang terjadi di mana NU mampu mengaplikasikan cita-cita agung itu ke dalam fakta kaderisasi dan pendidikan di bawah NU, walaupun di sana sini masih terdapat beberapa kekurangan yang perlu dibenahi.

D alam buku kaderisasi NU dijelaskan bahwa bukti ke-Qadiman al-Qur'an adalah kemukjizatan yang terkandung di dalamnya, sehingga tidak ada satu pun yang mampu membuat apalagi menandingi kehebatan Tuhan berupa al-Q ur'an ini. Untuk mengetahui seluruh isi al-Q ur'an berikut juga kemukjizatannya adalah melalui akal. Hal yang sama juga berlaku pada kitab 'Aqidat al-Anam karya Ahmad Marzuki dan kitab al-Hzisun alHæamidiyah karya Husein Muhammad. Kemudian Ahmad Marzuki menambahkan bahwa Kalam Tuhan adakalanya diperdengarkan sendiri oleh Tuhan dan adakalanya disampaikan melalui malaikat Jibril. Namun yang pasti adalah Kalam Tuhan tersebut bersifat azali> (Qadin) dan diturunkan tanpa huruf dan suara (bi lałharf wa lasăant).

c. Qadk'>dan Qadar Tuhan dan kehendak bebas manusia

Baik al-Ash'ari>maupun al-Maturidi>berpendapat bahwa Qadk'>dan Qadar Tuhan adalah sebuah keniscayaan yang sudah ditentukan di zaman azali>baik berupa perbuatan baik ataupun perbuatan buruk. Namun yang perlu digarisbawahi di sini, manusia bebas memilih antara melakukan kebaikan dan keburukan yang tentunya juga bertanggung jawab atas konsekuensi pilihannya tersebut. Jika memilih keburukan, maka dia dianjurkan untuk selalu bertaubat dan tidak mengulangi lagi, jika tidak bertaubat, maka pintu neraka sangat terbuka lebar baginya. Sebaliknya, jika manusia lebih memilih perbuatan baik dalam kehidupannya, maka Allah menjanjikan surga yang kenikmatannya tidak bisa dibayangkan oleh panca indera.

Cita-cita agung dari konsep teologi ini jauh berbeda dengan fakta NU pada tahap kaderisasi dan pendidikannya. Konsep Qadk’’dan Qadar dalam buku pengkaderan NU Jawa Timur lebih condong pada sikap pasrah pada ketentuan yang menjadi keniscayaan tanpa ada usaha yang dilakukan, sebuah konsep yang berkebalikan dengan konsep alAsh'ari ‘dan al-Maturidi yang memberikan ruang ikhtiyardan kasbpada diri manusia. Hal ini berbeda dengan konsep Qadk'' Qadar dalam kitab 'Aqidat al-'A wamdan al-Hzisun alHæamidiyah yang lebih mirip dengan konsep al-Ash'ari>dan al-Maturidi>walaupun masih ada sekat yang membedakan pada tahap rasionalisasi.

\section{Penutup}

Setelah membahas tentang relevansi antara cita-cita NU dalam Munas dan Muktamar tentang konsep teologi Ahl al-Sumnah wa al-Jamágh dan fakta yang terjadi dalam proses 
kaderisasi dan pendidikan NU, maka beberapa kesimpulan yang bisa diambil adalah 1) teologi NU dalam masalah ke-Esa-an Tuhan sesuai dengan harapan, walaupun masih perlu perbaikan dalam argumen-argumen yang mempunyai kecenderungan tekstual, 2) teologi NU dalam masalah ke-Qadiman al-Qur'an mendekati sempurna sesuai dengan harapan NU, akan tetapi argumen-argumennya cenderung tekstual dan tidak mencerminkan konsep teologi al-A sh'ari> dan al-Maturidi>3) teologi NU dalam masalah Qadá’dan Qadar Tuhan jauh dari konsep teologi al-Ash'ari>dan al-Maturidi>

\section{Daftar Rujukan:}

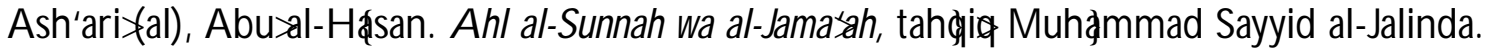
Mesir: Universitas Kairo, t.th.

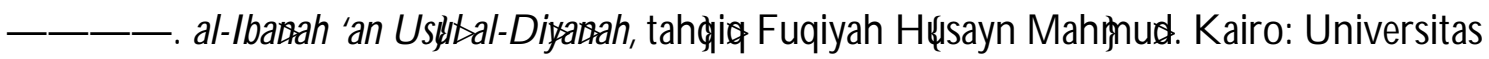
'Ayn al-Sham, 1998.

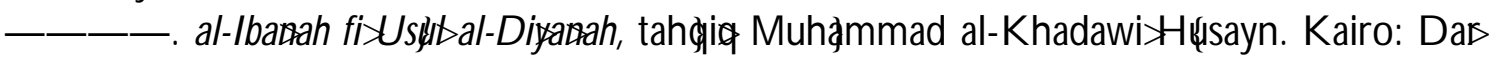
al-Q adiri> 1991.

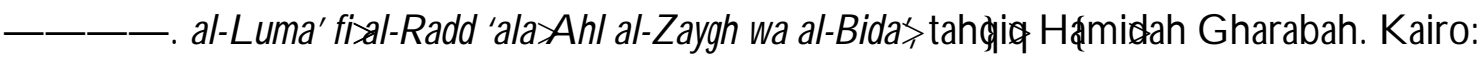
Maktab al-Azhas, t.th.

- - - - . Risalah ilaAh al-Saghar, tahdiri Abdullah Syakir Muhammad al-Jundi>Madinah: Maktabat al-Ulum wa al-Hukm, 1988.

Aziz, RS. Abdul. Konseps Ahl Surmah wal Jama’ah Pekalongan: CV. Bahagia, 1998.

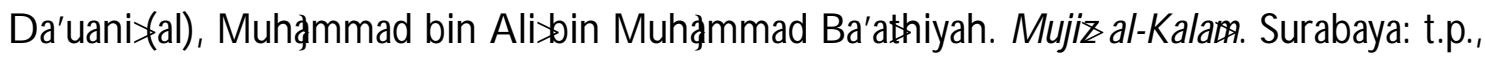
2009.

Maghrabiłal), 'Ali`Abd al-Fattah Imam. Ahl al-Sumnah waal-Jama'gh t.t.: Maktabah Wahbah, 1989.

Mahfudz, M. A. Sahal. Nuansa Fiqh Sosial. Yogyakarta: LKIS. 1994.

Masduqi, Ahmad. Konsep Dasar Pengetian Ahl Summah val Jama'ah Surabaya: Pelita D unia, 1986.

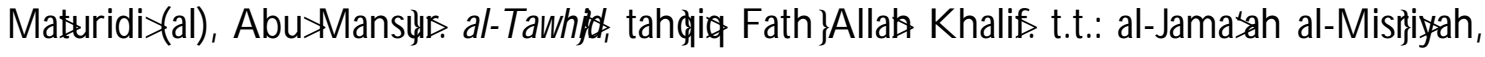
t.th.

Nasution, Harun. Telog Islam Jakarta: UI Press, 1986.

PBNU. Keputusan Munas Alim Ulama' dan Kombes NU di Bandar Lampung Jakarta: PBNU. 1992.

Pengarus Nahdlatul Ulama' Cabang Surabaya. Kdbangkitan Umat Idam dan Peranan NU di Indonesia Surabaya. t.p.: 1980.

Pengurus Wilayah NU Jatim. Keputusan Muktamar NU XXVII. Surabaya: Pengurus Wilayah NU Jatim. 1984.

Ruhiyat, Ilyas et al. Dinamika Kaum Muda, IPNU dan Tantangan Masa Depan Jakarta: PPIPNU, 1997.

Tharabulusi (al), Husein Afandi al-Jisr. al-Hisun al-Hamidiyah Surabaya: t.p., 1970.

Tim Penyusun. Ensklqped Indonesia Jilid 4. Jakarta: Ichtiar baru van Hoeve. 1980.

Wirano, Khotibul Umam. Menbaca UlangAsuaja dan Upaya Transfomasi PMII. Jakarta: PPPMII, 1997. 